\title{
A Review of Dry Sanitation Systems
}

\author{
Arturo Aburto-Medina ${ }^{1, * \mathbb{C}}$, Esmaeil Shahsavari ${ }^{1}{ }^{\mathbb{C}}$, Leadin S. Khudur ${ }^{1}$, Sandy Brown ${ }^{2}$ and \\ Andrew S. Ball ${ }^{1,3}$ (D) \\ 1 Centre for Environmental Sustainability and Remediation, School of Science, RMIT University, \\ Bundoora 3083, Australia; esmaeil.shahsavari@rmit.edu.au (E.S.); leadin.khudur@rmit.edu.au (L.S.K.); \\ andy.ball@rmit.edu.au (A.S.B.) \\ 2 Parks Victoria, Melbourne 3000, Australia; sandy.brown@parks.vic.gov.au \\ 3 ARC Training Centre for the Transformation of Australia's Biosolids Resource, RMIT University, \\ Bundoora 3083, Australia \\ * Correspondence: arturoaburto.medina@rmit.edu.au or aarturo1309@gmail.com
}

Received: 29 May 2020; Accepted: 12 July 2020; Published: 19 July 2020

\begin{abstract}
Dry sanitation systems (waterless or composting toilets) have been used since the 1970s. Their use has received acceptance in rural regions of Europe and the United States. Some of the advantages of dry sanitation systems include their waterless nature, their low energy requirement and the creation of fertilizer as an added value product. Moreover, the use of such a system is a sustainable sanitation approach that may reduce the burden on infrastructure and provide sanitation to the 2.5 billion people worldwide who do not currently have access to it. The critical factors when choosing a dry sanitation system and their optimum parameters include aeration, moisture content $(50 \%-60 \%)$, temperature $\left(40-65^{\circ} \mathrm{C}\right)$, carbon to nitrogen ratio $(25-35), \mathrm{pH}(5.5-8.0)$ and porosity $(35 \%-50 \%)$. The temperature-time criterion approach is the most common method used to evaluate the stability and safety of the compost as a fertilizer. The risks of handling the waste after 12 months of composting have been calculated as low. Here, we have reviewed and assessed the features of dry sanitation systems currently available, focusing on those designed for and operated in remote areas such as national parks and tourist destinations and, more importantly, in rural areas in developing countries or refugee shelters where water/sanitation may be scarce.
\end{abstract}

Keywords: dry sanitation systems; waterless toilets; composting toilets; fertilizer; sustainability

\section{Introduction}

The energy invested to produce drinking water for use in a flush toilet for wet sanitation is not a sustainable activity; there is a requirement for alternative sanitation options to be trialled and eventually put in place [1]. Although the use of greywater (water waste from all household activities except sewage) [2] and rainwater is one option currently being used to save precious drinkable water, this option is still linked to a central wet sanitation system. Therefore, an option independent from the central wet infrastructure, such as the waterless or composting toilet, which represents dry sanitation systems, remains a key option.

Dry sanitation systems have been used in the developed world since Rikard Lidstrom invented the first composting toilet in 1939 in Tyreso, Sweden. A patent was created in 1962, and the company Clivus Multrum started selling models in the 1970s.

Currently, there are manufacturers of dry sanitation systems in several countries around the world including Japan, the United States, Germany, Sweden and France [3-6]. Moreover, organizations promote both the manufacture and use of waterless and composting toilets in developing countries (e.g., Semarnat \& Tierramor in Mexico), and there are also manuals for their construction [7]. The main 
microorganisms reported to be involved in the composting process are bacteria, actinobacteria and fungi [8].

Dry sanitation systems have been mainly used in rural areas and those areas with water shortages [9-11], but their use in urban areas has also been studied [9]. A commercially available dry sanitation system (bio-toilet) has also been used in Japan in public parks, sightseeing locations and households [12].

The main advantages of the dry sanitation systems are the decentralization of a water system and the production of fertilizer for plants. This activity falls within the sustainability approaches required nowadays since the increasing world population (7.7 billion in 2020) is constantly adding more pressure to the already limited drinking water resources. More importantly, it could lower the number of gastrointestinal infections recorded in rural areas. Increased sanitation can be cost-beneficial; it has been observed that the return of $\$ 1$ invested in sanitation was in the range of $\$ 11.6-22.9$ [13]. However, information on dry sanitation systems is still scarce and there is a lack of peer-reviewed literature. Therefore, this review is based on the available peer-reviewed and grey literature $[14,15]$ and aims to compile information on the different types of commercially available dry sanitation systems with an emphasis on the large-capacity waterless toilets that require the least maintenance. Such models could provide an alternative for the growing ecotourism industry, ski and hiking areas, refugee shelters or rural/impoverished areas in developing countries suffering water shortages.

\section{Types of Dry Sanitation Systems}

Dry sanitation systems can be classified as self-contained or central, single or multi-layered chamber tank, mixing device, urine separating, electric or solar, and completely waterless or with low water usage (Table 1). Such features mainly depend on their intended location and their circumstances; e.g., solar-powered, with a multi-layer chamber and completely waterless will be selected for remote areas in national parks, while self-contained, electric and single layer could be used in a building within an urban setting.

Table 1. Types of dry sanitation systems available.

\begin{tabular}{ccccc}
\hline Type & Energy & Chamber Tank & Water Usage & Bulking Agent \\
\hline $\begin{array}{c}\text { Self-contained } \\
\text { Central }\end{array}$ & Solar & Single layer & Waterless & Needed \\
Electric & Multi-layer & Low water usage & Not needed \\
\hline
\end{tabular}

\subsection{Self-Contained or Central}

Self-contained refers to those where the composting chamber and the toilet are one unit. Central composting toilets have a much larger tank and can be connected to multiple toilets. Vertical piping is needed to direct the faecal matter to the composting tank.

\subsection{Single or Multi-Chambered Tank}

Single tank refers to toilets with only one chamber and where old and fresh waste is composted. Clivus Multrum, Phoenix and Sun-Mar are examples of commercial brands with single-chamber tank toilets.

Multi-chambered composting tanks usually have two or three chambers and are designed for the different stages of composting (composting, evaporating and finishing). Carousel composting is another version with four chambers; every time a chamber tank is full, the carousel is moved to the next chamber to collect fresh waste. Thus, when the fourth chamber is filled, the waste in the first chamber has been composted and is ready to be removed [16]. The Eco-Tech Carousel and BioLet companies have these models. Another model is a bio-drum that rotates the waste into different chambers, each for a different composting stage. 


\subsection{Electric and Non-Electric Toilets}

Electricity is used for fans, heating systems or to create a vacuum. The fan draws the air into the toilet, eliminating odours in the bathroom. In some dry sanitation systems, the air inside the toilet is heated and evaporates the excess liquid (BioLet). When a vacuum is created to convey the waste, a water flush is also usually used. Examples of electric toilets are the Phoenix and Nature-loo.

\subsection{Urine Separating and Combined Collection Toilets}

It has been estimated that $500 \mathrm{~L}$ of urine and $50 \mathrm{~L}$ of faeces are produced per person annually [17]. Separating the urine has the advantage of reducing the odours and excess liquid in the composting pile and has been recommended previously [18]. Moreover, the urine can be used as a fertilizer due to its low pathogen concentration and high nitrogen, potassium and phosphorus content [19]. Another study also found that vermicomposting toilets that separate the urine (or no-mix toilets) performed better in mass reduction, pathogen destruction, compost quality and operational cost than the ones not separating the waste [20].

\section{Factors Affecting Aerobic Composting Toilets}

In general, a dry sanitation system works by converting the waste into compost that can later be used as fertilizer for crops. Compost is a mixture of decomposing manure or vegetable waste, where the decomposition is carried out aerobically by specific microorganisms that include bacteria, fungi and actinomycetes [21,22]. Four stages of the compost can be defined: (1) the mesophilic phase, (2) the thermophilic phase, (3) the cooling phase and 4) the curing phase [23]. In the initial decomposing stage, mesophilic bacteria such as Escherichia coli and other Enterobacteria produce $\mathrm{CO}_{2}$ and energy that is partially used for reproduction and growth and the rest is released as heat, raising the compost temperature to $44{ }^{\circ} \mathrm{C}$. This is followed by the thermophilic microorganisms that further raise the temperature to $65^{\circ} \mathrm{C}$, and in this process the pathogens are killed. At the cooling phase, the mesophilic microorganisms take over again and continue digesting the more resistant organic materials. Humus is produced by fungi and other microorganisms such as earthworms and sowbugs. The last step in the composting process called curing, aging or maturing is long and should last around 12 months after the thermophilic phase to make sure pathogens have been destroyed [23]. This was confirmed by a study that found the risks of handling the compost after 12 months are low. This study is described in more detail below [24].

The microbial diversity in compost has been elucidated and is shown in Table 2. A more recent study on a hot synthetic compost has confirmed the dominance of Bacillus [25] among other genera. As mentioned, it is the mesophilic and thermophilic bacteria that increase the temperature, followed by the actinomycetes and, in turn, by fungi during the later stages of the process. Although the appropriate choice of microorganisms is critical for the compost, factors such as temperature, aeration, $\mathrm{pH}$, carbon/nitrogen ratio and moisture can affect the proper operation of the compost and, therefore, are discussed below. Optimum values for these factors are shown in Table 3. 
Table 2. The microbial diversity in a compost. Adapted from [21].

\begin{tabular}{ccc}
\hline Actinomycetes & Fungi & Bacteria \\
\hline & & Alcaligenes faecalis \\
Actinobifida chromogena & & Bacillus brevis \\
Microbispora bispora & & B. circulans complex \\
Micropolyspora faeni & Aspergillus fumigatus & B. coagulans type A \\
Nocardia sp. & Bumicola grisea & B. coalans type B \\
Pseudonocardia thermophilia & H. insolens & B. megaterium \\
Streptomyces rectus & H. lanuginosa & B. pumilus \\
S. thermofuscus & Malbranchea pulchella & B. sphaericus \\
S. thermoviolaceus & Myriococcum themophilum & B. stearothermophilus \\
S. thermovulgaris & Paecilomyces variotti & B. subtilis \\
S. violaceus-ruber & Papulaspora thermophila & Clostridium thermocellum \\
Thermoactinomyces sac & Scytalidium thermophilim & Escherichia coli \\
chari & Sporotrichum thermophile & Flavobacterium sp. \\
T. vulgaris & & Pseudomonas sp. \\
Thermomonospora curvata & & Serratia sp. \\
T. viridis & & Thermus sp. \\
\hline
\end{tabular}

Table 3. Optimum values of factors affecting aerobic composting.

\begin{tabular}{cccccc}
\hline $\begin{array}{c}\text { Carbon/Nitrogen } \\
\text { Ratio }\end{array}$ & Aeration & $\mathbf{p H}$ & Temperature & $\begin{array}{c}\text { Particle Size } \\
\text { and Porosity }\end{array}$ & $\begin{array}{c}\text { Moisture } \\
\text { Content }\end{array}$ \\
\hline $25-35$ & $\begin{array}{c}15 \% \text { to } 20 \% \\
\text { range }\end{array}$ & 5.5 to 8.0. & $19-65{ }^{\circ} \mathrm{C}$ & $\begin{array}{c}35 \%-50 \% \\
\text { porosity }\end{array}$ & $50 \%-60 \%$ \\
\hline
\end{tabular}

\subsection{Carbon/Nitrogen Ratio}

The carbon and nitrogen composition of human faeces decreases during the composting process. Around $66 \%$ of faecal nitrogen converts to ammonia while $34 \%$ remains as biologically inert nitrogen [26]. Similarly, $80 \%$ of carbon converts to $\mathrm{CO}_{2}$ while $20 \%$ stays in the compost [27]. Thus, the loss of $\mathrm{N}$ and $\mathrm{C}$ as gas emissions (ammonia and $\mathrm{CO}_{2}$ ) reduces the nutrient and agronomic value of the compost. However, high mineralization results in a mature compost due to reduced leaching and volatilization when applied to plants [28]. The addition of bulking agents with a high lignocellulose content (e.g., sawdust) decreases the loss of nitrogen [29]. The $\mathrm{C}$ and $\mathrm{N}$ loss depends on the bulking agent and the composting process [28].

A carbon to nitrogen ratio of 25-35 has been recommended for the composting of municipal waste and sewage sludge [30]. The C: $\mathrm{N}$ ratio in human faeces is deficient in carbon $(\mathrm{C}: \mathrm{N}=8)$. Therefore, to increase the carbon content in the compost, several bulking agents such as sawdust, wood chips, grass cuttings, dried leaves, kitchen waste and toilet paper can be added [31].

\subsection{Aeration}

Aerobic conditions should be maintained since a lack of oxygen produces odour issues and the composting rate is lowered. However, an excess of airflow may remove water vapour from the compost. The amount of air is inversely proportional to that of the moisture. Previous studies have suggested an optimum oxygen concentration within the $15 \%$ to $20 \%$ range [32].

\section{3. $p H$}

It has been observed that $\mathrm{pH}$ usually decreases during the composting process due to the conversion of carbonaceous material to organic acidic intermediates; $\mathrm{pH}$ also increases as the temperature increases [30]. Thus, studies have recommended an optimum $\mathrm{pH}$ range of 5.5 to 8.0 [30,32], while a pH within the 6.7-9.0 range has been suggested for animal manure composting and prevents nitrogen loss by ammonia [29]. 


\subsection{Temperature}

Composting is performed initially by mesophilic organisms at a temperature range of $19-45^{\circ} \mathrm{C}$ and is followed by thermophilic organisms at a temperature above $45^{\circ} \mathrm{C}$, increasing the composting rate $[23,33]$. Most of the organic degradation and pathogen destruction occurs within the $50-65^{\circ} \mathrm{C}$ range $[28,34]$. As the temperature reduces, mesophilic organisms take over again and break down the remaining compounds.

Optimum temperatures for composting have been suggested as $40-65{ }^{\circ} \mathrm{C}$ [30] and $60{ }^{\circ} \mathrm{C}$ [35], but temperatures $>65{ }^{\circ} \mathrm{C}$ prevent the composting process [36]. An optimum temperature can be obtained by insulation, turning and electric heaters [37,38]. Turning the compost is an efficient way to obtain the optimum temperature. The Envirolet manufacturers claim that their models are ideal to work in low temperatures.

\subsection{Particle Size and Porosity}

Porosity increases with the particle size, and this is important in balancing the surface area for growth of microorganisms. A large particle size increases the porosity and lowers the surface area to mass ratio. Thus, a value of $35 \%-50 \%$ porosity is best for composting [28].

\subsection{Moisture Content}

Moisture in faeces, urine or foam flush makes the nutrients physically and chemically accessible to microorganisms. A moisture content of $82 \%$ has been reported in faeces [33]. Several composting systems remove excess moisture since too much may create unwanted anaerobic conditions. However, if the moisture levels are below $40 \%$ the decomposition process slows down and activation water is needed [39]. According to several studies, a moisture content of $50 \%-60 \%$ is the optimum for proper composting [35,40], while an upper limit of $65 \%$ has also been proposed [35].

\section{Microbial Risks of Faecal Matter Manipulation}

The microbial risks of handling faecal matter have been assessed in a study that calculated the risks associated with the local handling and use of human faeces during the maintenance of composting toilets in Danish houses [24]. Manual emptying is more common for self-contained toilets in private households, while emptying of those with larger capacity may be performed with machinery and professional services. The human exposures assessed included accidental ingestion of a small amount of faeces or a mixture of soil and faeces while emptying the storage container. Inactivation of pathogens to acceptable levels was achieved after 12 months of storage [24]. Although the risks of transmission after one year of storage may still be high for some viruses, simple practices such as wearing gloves and face protection lower the risk significantly. The organisms included in the risk assessment were: Salmonella, enterohaemorrhagic E. coli (EHEC) (bacteria), Rotavirus, Hepatitis A (virus), Giardia, Cryptosporidium and Ascaris (parasites). The typical risks of emptying an infected container after a year are negligible for Salmonella, EHEC and Giardia while they are very low for Rotavirus, Hepatitis A, Cryptosporidium and Ascaris, respectively. The authors also calculated that the risk of infection from bacteria is low, regardless of the incidence rate in the population. Therefore, it is critical to keep the storage time to a minimum of 12 months to prevent any infection.

\section{Commercial Dry Sanitation Systems Currently on the Market}

Some of the most common commercially available dry sanitation systems for houses and public facilities are listed in Appendix A (Supplementary information), and they include self-contained or central, urine-diverting, electrical, and single or multi-chambered. Although these toilets are more expensive than flush toilets, the cost in the long term will be lower than the flushing ones [13] since water bills will be significantly lowered. However, to date, there is no standard guideline for composting toilets, which creates a lack of consistency in the presentation of toilet capacity. Some 
factors to take into consideration when choosing the right dry sanitation system are the capacity, which is the number of uses/day, the availability of electricity, the population density, position of the composter (ground level or above) and climatic conditions, among others. It is also important to note that most of the models require frequent maintenance for their proper functioning. Adding bulking agents, spraying liquids and mixing the compost pile are critical to maintaining a good rate of decomposition.

\section{Commercially Available Dry Sanitation Systems Intended for Remote Areas (National Parks, Rural Areas)}

Central waterless toilets have a much larger tank and can be connected to multiple toilets. Vertical piping is needed to direct the faecal matter to the composting tank. They are designed for greater capacity systems and are usually required at public facilities such as national parks. Clearance of the underfloor is required for some of them, thus the compost treatment chamber is below the floor and separated from the toilet pedestal by a chute.

A few models were selected for further discussion because they are intended for remote areas such as national parks without access to water or electricity; they are also intended for large capacities (they have the largest composting tanks) and they require the least maintenance. Each of these models is described and compared in Appendix B (Supplementary information).

\section{Future of Dry Sanitation Systems}

Alternative options (not commercially available) include toilets using nanotechnology and solar power. In addition, the separation of urine to be used later as fertilizer has been advocated as a sustainable solution. Urine is nitrogen rich $(75 \%-90 \%$ contributed by urea), and its phosphate and potassium compounds are readily water soluble and available for plants [41]; urine also has a low concentration of heavy metals compared to synthetic fertilizers [42]. Thus, its collection in diverting toilets represents a good alternative to conventional sanitation systems and it has been implemented in several developed and developing countries [43].

Some projects funded by the Bill and Melinda Gates foundation [42] include designs/prototypes such as a solar-powered toilet that generates hydrogen and electricity by CalTech, a toilet that produces biological charcoal, minerals and clean water, designed by Loughborough University, and a toilet that sanitizes faeces and urine while recovering resources and clean water, designed by the University of Toronto [44]. A toilet user interface designed by the Eawag has also been recognized.

A nanomembrane toilet was designed by researchers from Cranfield University and was also funded by the Bill and Melinda Gates Foundation in September 2012 [45]. This toilet is intended for urban poor areas because it requires maintenance only every six months. It uses thin nanofibres arranged in bundles inside the chamber that help move the water vapour through beads that condense the vapour into water. The solid waste is left to dry in a holding chamber until a technician removes it [45].

Thus, the future of dry sanitation systems appears promising. This review categorizes these systems and provides the latest commercially available models, with an emphasis on those with large capacities which require the least maintenance. We also aimed to describe the principal factors required to maintain an efficient composting process and, in general, to increase awareness of dry sanitation systems as a sustainable alternative for waste management, especially for remote and rural areas, as well as refugee shelters where water may be limited.

Supplementary Materials: The following are available at http://www.mdpi.com/2071-1050/12/14/5812/s1.

Author Contributions: Conceptualization, S.B.; methodology, A.A.-M. and A.S.B.; validation, A.S.B. and S.B.; formal analysis, A.A.-M. and A.S.B.; investigation, A.A.-M. and L.S.K.; resources, A.S.B. and S.B.; data curation, A.A.-M., L.S.K. and A.S.B.; writing-original draft preparation, A.A.-M.; writing-review and editing, A.A.-M., L.S.K., E.S., and A.S.B.; supervision, A.S.B.; project administration, A.S.B.; funding acquisition, A.S.B. All authors have read and agreed to the published version of the manuscript.

Funding: This research was funded by Parks Victoria. 
Conflicts of Interest: The authors declare no conflict of interest.

\section{Appendix A}

Commercially available dry sanitation systems for houses and public facilities.

\section{Appendix B}

Commercially available dry sanitation systems intended for remote areas without access to water or electricity; they are also intended for large capacities.

\section{References}

1. Maher, M.; Lustig, T. Sustainable water cycle design for urban areas. Water Sci. Technol. 2003, 47, 25. [CrossRef]

2. Zhao, S. Re-Bathroom_Thermal and Grey Water Reuse System in a Domestic Bathroom. Ph.D. Thesis, Politecnico di Torino, Torino, Italy, 2019.

3. Kitaoka, S. Sustainable development goals and Japan's official development assistance policy: Human security, national interest, and a more proactive contribution to peace. Asia Pac. Rev. 2016, 23, 32-41. [CrossRef]

4. Lourenço, N.; Nunes, L.M. Review of Dry and Wet Decentralized Sanitation Technologies for Rural Areas: Applicability, Challenges and Opportunities. Environ. Manag. 2020, 65, 642-664. [CrossRef]

5. Nasri, B.; Brun, F; Fouché, O. Evaluation of the quality and quantity of compost and leachate from household waterless toilets in France. Environ. Sci. Pollut. Res. 2019, 26, 2062-2078. [CrossRef]

6. Drangert, J.-O. Nutrient Recycling: Waste Hierarchy, Recycling Cities and Eco-houses. In Sustainable Agriculture Reviews 32; Lichtfouse, E., Ed.; Springer: Cham, Switzerland, 2018; Volume 32, pp. 1-17.

7. Crennan, L. Sustainable sanitation manual and construction guidelines for a waterless composting toilet. IWP Pac. Tech. Rep. 2007, 52, 1-31.

8. Rebollido, R.; Martinez, J.; Aguilera, Y.; Melchor, K.; Koerner, I.; Stegmann, R. Microbial populations during composting process of organic fraction of municipal solid waste. Appl. Ecol. Environ. Res. 2008, 6, 61-67. [CrossRef]

9. Cordova, A.; Knuth, B.A. Barriers and strategies for dry sanitation in large-scale and urban settings. Urban Water J. 2005, 2, 245-262. [CrossRef]

10. Fittschen, I.; Niemczynowicz, J. Experiences with dry sanitation and greywater treatment in the ecovillage Toarp, Sweden. Water Sci. Technol. 1997, 35, 161. [CrossRef]

11. Kaczala, F. A Review of Dry Toilet Systems; Department of Technology, University of Kalmar: Kalmar, Sweden, 2006.

12. Zavala, M.A.L.; Funamizu, N.; Takakuwa, T. Biological activity in the composting reactor of the bio-toilet system. Bioresour. Technol. 2005, 96, 805-812. [CrossRef] [PubMed]

13. Hallegatte, S.; Rentschler, J.; Nicolas, C.; Fox, C. Strengthening New Infrastructure Assets: A Cost-Benefit Analysis; The World Bank: Washington, DC, USA, 2019. [CrossRef]

14. Anand, C.; Apul, D.S. Economic and environmental analysis of standard, high efficiency, rainwater flushed, and composting toilets. J. Environ. Manag. 2011, 92, 419-428. [CrossRef] [PubMed]

15. Berger, W. Basic overview of composting toilets (with or without urine diversion). In Technology Review "Composting Toilets"; Deutsche Gesellschaft für Technische Zusammenarbeit (GTZ) GmbH: Eschborn, Alemanha, 2010.

16. Del Porto, D.; Steinfeld, C. Operating and Maintaining your Composting Toilet System. In The Composting Toilet System Book; Center for Ecological Pollution Prevention: Concord, MA, USA, 2000; pp. 1-234.

17. Drangert, J. Fighting the urine blindness to provide more sanitation options. Water SA-Pretoria 1998, 24, $157-164$.

18. Jönsson, H.; Vinnerås, B. Experiences and suggestions for collection systems for source-separated urine and faeces. Water Sci. Technol. 2007, 56, 71. [CrossRef] [PubMed]

19. Randall, D.; Naidoo, V. Urine: The liquid gold of wastewater. J. Environ. Chem. Eng. 2018, 6, 2627-2635. [CrossRef] 
20. Hill, G.B.; Baldwin, S.A. Vermicomposting toilets, an alternative to latrine style microbial composting toilets, prove far superior in mass reduction, pathogen destruction, compost quality, and operational cost. Waste Manag. 2012, 32, 1811-1820. [CrossRef] [PubMed]

21. Palmisano, A.C.; Barlaz, M.A. Microbiology of Solid Waste; CRC Press: Boca Raton, FL, USA, 1996; Volume 3, pp. 71-104.

22. Beffa, T.; Blanc, M.; Marilley, L.; Fischer, J.L.; Lyon, P.-F.; Aragno, M. Taxonomic and Metabolic Microbial Diversity during Composting. In The Science of Composting; de Bertoldi, M., Sequi, P., Lemmes, B., Papi, T., Eds.; Springer: Dordrecht, The Netherlands, 1996; pp. 149-161. [CrossRef]

23. Jenkins, J. The humanure handbook. In A Guide, 3rd ed.; Chelsea Green Publishing: Grove City, PA, USA, 2005.

24. Schönning, C.; Westrell, T.; Stenström, T.A.; Arnbjerg-Nielsen, K.; Hasling, A.B.; Høibye, L.; Carlsen, A. Microbial risk assessment of local handling and use of human faeces. J. Water Health 2007, 5, 117-128. [CrossRef] [PubMed]

25. Dees, P.M.; Ghiorse, W.C. Microbial diversity in hot synthetic compost as revealed by PCR-amplified rRNA sequences from cultivated isolates and extracted DNA. FEMS Microbiol. Ecol. 2001, 35, 207-216. [CrossRef]

26. Hotta, S.; Noguchi, T.; Funamizu, N. Experimental study on nitrogen components during composting process of feces. Water Sci. Technol. 2007, 55, 181. [CrossRef]

27. Orner, K.D.; Mihelcic, J.R. A review of sanitation technologies to achieve multiple sustainable development goals that promote resource recovery. Environ. Sci. Water Res. Technol. 2018, 4, 16-32. [CrossRef]

28. Bernal, M.P.; Alburquerque, J.A.; Moral, R. Composting of animal manures and chemical criteria for compost maturity assessment. A review. Bioresour. Technol. 2009, 100, 5444-5453. [CrossRef]

29. Sánchez-Monedero, M.A.; Roig, A.; Paredes, C.; Bernal, M.P. Nitrogen transformation during organic waste composting by the Rutgers system and its effects on $\mathrm{pH}, \mathrm{EC}$ and maturity of the composting mixtures. Bioresour. Technol. 2001, 78, 301-308. [CrossRef]

30. De Bertoldi, M.D.; Vallini, G.E.; Pera, A. The biology of composting: A review. Waste Manag. Res. 1983, 1, 157-176. [CrossRef]

31. Depledge, D. Design Examples of Waterless Composting Toilets; South Pacific Applied Geoscience Commission (SOPAC): Miscellaneous Report 249. Available online: http://www.pacificwater.org/userfiles/ file/MR0249.pdf (accessed on 18 July 2020).

32. Miller, F.C. Composting as a process based on the control of ecologically selective factors. Microb. Ecol. 1993, 515-544.

33. Lopez Zavala, M.A.; Funamizu, N.; Takakuwa, T. Characterization of Feces for Describing the Aerobic Biodegradation of Feces. Doboku Gakkai Ronbunshu 2002, 720, 99-105. [CrossRef]

34. Nataka, S.; Lopez Zavala, M.; Funamizu, N.; Otaki, M.; Takakuwa, T. Temperature effect on pathogens decline in the bio-toilet system. In Proceedings of the 1st International Dry Toilet Conference: Dry Toilet, Tampere, Finland, 20-23 August 2003.

35. Lopez Zavala, M.A.; Funamizu, N. Design and operation of the bio-toilet system. Water Sci. Technol. 2006, 53, 55. [CrossRef] [PubMed]

36. Germer, J.; Boh, M.Y.; Schoeffler, M.; Amoah, P. Temperature and deactivation of microbial faecal indicators during small scale co-composting of faecal matter. Waste Manag. 2010, 30, 185-191. [CrossRef]

37. Epstein, E. The Science of Composting; CRC Press: Lancaster, PA, USA, 1996; p. 487.

38. Haug, R.T. The Practical Handbook of Compost Engineering; CRC Press/Routhledge: Boca Raton, FL, USA, 2018; p. 717.

39. Yamada, Y.; Kawase, Y. Aerobic composting of waste activated sludge: Kinetic analysis for microbiological reaction and oxygen consumption. Waste Manag. 2006, 26, 49-61. [CrossRef] [PubMed]

40. Poincelot, R.P. Scientific examination of principles and practice of composting. Compost Sci. 1974, 15, $24-31$.

41. Richert, A.; Gensch, R.; Jönsson, H.; Stenström, T.A.; Dagerskog, L. Practical Guidance on the Use of Urine in Crop Production; SEI: Stockholm, Sweden, 2010.

42. Hennigs, J.; Parker, A.; Collins, M.; Jiang, Y.; Kolios, A.; McAdam, E.; Williams, L.; Tyrrel, S. Planning and communicating prototype tests for the Nano Membrane Toilet: A critical review and proposed strategy. Gates Open Res. 2019, 3, 1532. [CrossRef]

43. Simha, P.; Ganesapillai, M. Ecological Sanitation and nutrient recovery from human urine: How far have we come? A review. Sustain. Environ. Res. 2017, 27, 107-116. [CrossRef] 
44. Cruddas, P.; Parker, A.; Gormley, A. User perspectives to direct water reuse from the Nano Membrane Toilet. In Proceedings of the 38th International WEDC Conference: Water, Sanitation and Hygiene Services Beyond 2015-Improving Access and Sustainability, Loughborough, UK, 27-31 July 2015; p. 6.

45. Perez Lopez, E. Design and Testing of a Novel Human-Powered Generator Device as a Backup Solution to Power Cranfield's Nano-Membrane Toilet. Master's Thesis, Cranfield University, Bedford, UK, 2014.

(C) 2020 by the authors. Licensee MDPI, Basel, Switzerland. This article is an open access article distributed under the terms and conditions of the Creative Commons Attribution (CC BY) license (http://creativecommons.org/licenses/by/4.0/). 